\title{
KNOWLEDGE, ATTITUDE, AND PRACTICE TOWARDS DENGUE FEVER AMONG PATIENTS IN HOSPITAL TAIPING
}

Mohammed Abdelfatah Alhoot ${ }^{1^{*}}$, Mohammed Faez Baobaid ${ }^{2}$, Anis Rageh Al-Maleki ${ }^{3,4}$, Mohammed A. Abdelqader ${ }^{2}$, Lavannya A/P Rangas Paran ${ }^{1}$, Bavani A/P Kannaiah1, Kavitha A/P Balasingam ${ }^{1}$, Mathuri A/P Appanu ${ }^{1}$, Paveetran A/L Bathmanathan ${ }^{1}$ and Murugan A/L Maniam ${ }^{1}$

\author{
${ }^{1}$ Medical Microbiology Unit, International Medical School (IMS), Management \& Science University (MSU), Shah Alam, \\ 40100, Selangor, Malaysia \\ ${ }^{2}$ Community Medicine Unit, International Medical School (IMS), Management \& Science University (MSU), Shah Alam, \\ 40100, Selangor, Malaysia \\ ${ }^{3}$ Department of Restorative Dentistry, Faculty of Dentistry, University of Malaya, Lembah Pantai, 50603 Kuala \\ Lumpur, Malaysia. \\ ${ }^{4}$ Department of Medical Microbiology, Faculty of Medicine and Health Sciences, Sana'a University, Sana'a, Yemen.
}

*Corresponding Author

Mohammed AbdelfatahAlhoot

E-Mail: malhoot@hotmail.com

\section{ABSTRACT}

Dengue fever is the most common vector-borne disease and major concern issues in Malaysia. Thus, the present study aimed to evaluate factors influencing knowledge, attitude, and practices regarding dengue fever among patients in Hospital Taiping. A total of 300 patients were incorporated into a descriptive, public based cross-sectional study. The questionnaires were formulated to include several questions on demographic data, knowledge, attitudes, and practices concerning dengue fever. Most of the respondents were from the age group of more than 35 (43.3\%). The largest representations of the participants were Malay (59.3\%), married (65.7\%), SPM is the highest education level (53.3\%), and $60.7 \%$ of the participants were conscious about dengue fever eruption. Television/radio was voted as the frequent source of information (97.3\%). There is no significant relationship between knowledge score and sociodemographic factors. However, around $57.0 \%$ of the respondents believe that abdominal pain is not a symptom of dengue fever and $32 \%$ convinced that blood transfusion can transmit dengue. No significant correlation was found between attitude and practice score to socio-demographic characters. However, a good practice towards dengue fever is associated with good knowledge (65.4\%) nevertheless it did not influence their attitude. Moreover, the attitude seems to be poor regardless of knowledge level (44.0\%). Therefore, more prevention practices to raise the awareness of population toward dengue fever such as health campaigns and health education in school level should be initiated. These activities will aid in fertilizing better attitude and prevention practice towards dengue fever and bring down its incidence in Malaysia.

KEYWORDS: Dengue fever, Malaysia, Hospital Taiping, Knowledge, Attitudes, Awareness, Practices

\section{INTRODUCTION}

Dengue fever is caused by Dengue viruses (DENV 1-4), which are transmitted to human hosts by Aedes mosquitoes. It is the most common vectorborne viral infection. Severe dengue is a leading cause of serious illness and death in many countries. Until now, there is no specific antiviral drug for treatment despite the intensive researches on different antiviral strategies ${ }^{(1-8)}$. Early detection and access to proper medical care lower fatality rates below $1 \%{ }^{(9)}$. The Prevention and control depend on effective vector control measures which are based on community education and contribution (10). Recently, dengue vaccine has been licensed by several National Regulatory Authorities to be used in public living in endemic settings with age of $9-45$ years ${ }^{(11)}$.

The initially recorded epidemics of dengue-like illness was in Cairo, Egypt, and Batavia,
Indonesia in $1779{ }^{(12)}$. However, the global incidence of the disease has been expanded dramatically in the last five decades ${ }^{(13)}$ with about 3.9 billion people under the risk of infection (14). Recently, it has been estimated that 284-528 million dengue infections per year, of which 67-136 million manifests clinically severe disease ${ }^{(15)}$. Currently, dengue is endemic in 128 countries ${ }^{(14)}$ in whereby five out of the six World Health Organization (WHO) regions were involved compared to only nine countries in 1970 (16). Approximately $75 \%$ of the global dengue infection burden is in the WHO South-East Asia and Western Pacific regions ${ }^{(17)}$.

In Malaysia, dengue fever was first reported in 1902 following an outbreak in Penang ${ }^{(18)}$. A few other outbreaks were also reported later in Penang and Kuala Lumpur ${ }^{(19)}$. However, by 1960 dengue had become endemic in Malaysia and the first laboratory-confirmed dengue hemorrhagic fever case was reported in Penang in $1962^{(20)}$. 
Currently, all the four serotypes of dengue viruses were co-circulating in Malaysia and implicated to cause outbreaks of dengue fever and dengue hemorrhagic fever in Malaysia ${ }^{(21)}$. The increasing dengue incidence rate was recorded following the 1980s onwards. The incidence rate ranged from as low as 8.42 cases per $10^{5}$ populations in 1988 to a high as 396.4 cases per $10^{5}$ populations in $2015^{(22)}$. According to the director general of health Malaysia Ministry of Health $(\mathrm{MOH})$, there is a total of 120,000 dengue cases and 322 deaths reported in 2015 (23) with intensely high activity so far compared with 19,884 dengue cases and 36 deaths reported in $2011^{(24)}$. It is very alarming incident to Malaysian health authorities as dengue has no cure and can be prevented only via disrupting the life cycle of vector but not by immunizations. Moreover, reducing the incidence of dengue highly dependent on the knowledge, attitude and practice of citizens towards dengue diseases. Furthermore, human habits are also highly associated with epidemiology and ecology of dengue diseases.

Therefore, this study is performed to study and analyze the knowledge, attitude, and practice toward dengue fever among patients in Hospital Taiping. The relevance of this study is raised up because dengue fever is still the major public health concern in Malaysia despite many implanted national programs on education and eliminating mosquito like Communication for Behavioural Impact (COMBI) Program. This study will highlight the role of all citizens and collaborations of the society with the government to reduce the dengue transmission cycle. So, in the future, we can focus on those factors to increase the awareness among the society.

\section{MATERIALS AND METHODS}

\section{Study design and source population}

A descriptive cross-sectional study was conducted among patients of medicine ward and parents of patients in the pediatric ward of Hospital Taiping as hospital staffs were excluded.

\section{Sampling method and sample size calculation} Simple random sampling was chosen to select the study participants. The sample size was calculated by statistical Epi Info ${ }^{T M}$ version 7.1.3 program (Centre for Disease Control, Atlanta, USA) using 95\% confidence limit and a value equal to 0.05 . Accordingly, the sample size calculated was 236 subjects and $20 \%$ was added to make the total of 284 respondents.

\section{Research tool}

Data was collected based on questionnaires from the previous study in Malaysia. The questionnaire was validated by International Medical School, Management and Science University, Shah Alam $^{(25)}$. It has been written in Bilingual and consisting of 67 questions that have been divided into four parts; Part $A$ is the demographic information. Meanwhile, part B consists of 25 questions that have been used to assess knowledge towards dengue fever. The response option would be 'yes' or 'no'. Every true answer will be given 1 point whereas 0 points will be given for every false answer.

Part C consists of 15 questions that have been used to assess the attitude towards dengue. The response options for this question will agree or disagree. A positive attitude will be given 1 point, and the negative attitude will be given 0 points. Finally, part D consists of 20 questions that have been used to assess practice towards dengue infection. Response option included 'yes' or 'no'. If the answer was 'yes', 1 point is given and 0 points for answer 'no'. Amendments have been made to the questionnaires to suit the researchers' interests excluding the options 'semirural', for the ease of data calculation.

For assessing the prevalence, the subject was divided into good knowledge and poor knowledge. Those scoring above the mean score werecategorized as good knowledge while those below the mean were categorized as poor knowledge. There were nine questions to determine the sources of information about dengue infection.

\section{Ethics and consent}

This study has been approved to be carried out by Jabatan Kesihatan Negeri, Perak DarulRidzuan (Bil (47) JKN.PK.BU/LAT/156/20 Jld.11) dated 24 Ogos 2015. Ethical approval was grantedbyMedicalResearch\& Ethics Committee, d/a InstitutPengurusan Kesihatan, Kementerian Kesihatan Malaysia ((5) KKM/NIHSEC/P15-1491) dated30 November 2015. The study methodology was also reviewed and recommended for ethical approval by the Institute for Health Behavioural Research (IHBR) (NMRR ID NMRR-15-1627-27280 S2 R0) dated 27/11/2015.

\section{Data collection}

Data collection began after the approval of the study proposal from the Research Committee at Management and Science University (MSU). A cover letter was attached to each questionnaire to assure that the participant's information is confidential. Patients were given a briefing backgroundbeforethequestionnaires distribution. Permission was taken directly from the patients by filled the consent form then collected data were obtained by answering a self-administered questionnaire.The questionnaire comprises of close-ended questions. The session has been 
ended within 20 minutes and the study data stored in the researcher's personal computer.

\section{Data analysis}

Data were verified and analyzed using the IBM Statistical Package for the Social Sciences (SPSS) version 20.0 software for Windows (IBM Corp., Armonk, NY, USA). Data were presented using Descriptive analysis and Inferential statistics. To identify the predictors of poor knowledge and practice, independent and dependent variables were converted into scores (One for true and Zero for false) and categorized as poor and good.

\section{RESULTS}

Socio-demographic characteristics of respondents

A total of 300 participants were included in this study. The majority of participants were female $(64 \%)$, and the rest were male $(36 \%)$. The race of participants found 59.3\% Malay, 22\% Indian, 15\% Chineseand $3.7 \%$ other races. For sociodemographic variables, $78 \%$ of the participants come from the low socioeconomic background whereby the family monthly income was less than RM 3000 . The remaining $22 \%$ had an income of more than RM 3000. Regarding living area, $57.3 \%$ of the participants live in an urban area whereas $42.7 \%$ of them live in rural area. Socio-demographiccharacteristics of the respondents are shown in Table 1.

Table 1: Socio-demographic characteristics of respondents $(\mathrm{N}=300)$.

\begin{tabular}{|c|c|}
\hline Characteristics & Respondent distribution (\%) \\
\hline \multicolumn{2}{|l|}{ Gender } \\
\hline Male & $108(36.0 \%)$ \\
\hline Female & $192(64.0 \%)$ \\
\hline \multicolumn{2}{|l|}{ Race } \\
\hline Malay & $178(59.3 \%)$ \\
\hline Chinese & $45(15.0 \%)$ \\
\hline Indian & $66(22.0 \%)$ \\
\hline Others & $11(3.7 \%)$ \\
\hline \multicolumn{2}{|l|}{ Age groups (years) } \\
\hline$<20$ & $31(10.3 \%)$ \\
\hline $20-24$ & $44(14.7 \%)$ \\
\hline $25-29$ & 37 (12.3\%) \\
\hline $30-34$ & $58(19.3 \%)$ \\
\hline$>35$ & $130(43.3 \%)$ \\
\hline \multicolumn{2}{|l|}{ Marital status } \\
\hline Single & 99 (33.0\%) \\
\hline Married & $197(65.7 \%)$ \\
\hline Divorced & $4(1.3 \%)$ \\
\hline \multicolumn{2}{|l|}{ Family monthly income } \\
\hline$<$ RM 3000 & 234 (78.0\%) \\
\hline$>$ RM 3000 & $66(22.0 \%)$ \\
\hline \multicolumn{2}{|l|}{ Living area } \\
\hline Rural & $128(42.7 \%)$ \\
\hline Urban & $172(57.3 \%)$ \\
\hline \multicolumn{2}{|l|}{ Higher education level } \\
\hline Below SPM & $31(10.3 \%)$ \\
\hline SPM & $160(53.3 \%)$ \\
\hline Diploma & $65(21.7 \%)$ \\
\hline Degree & $38(12.7 \%)$ \\
\hline Master & $6(2.0 \%)$ \\
\hline
\end{tabular}

Knowledge of dengue fever and sources of information

Most the participants $60.7 \%$ were aware of dengue fever and its outbreak in Malaysia. The sources of their information claimed mainly from television/radio $97.3 \%$, followed by newspaper $90.7 \%$, brochures $80.7 \%$, hospitals $78.7 \%$, health workers $74.7 \%$, and the least information other sources such as social media $66.0 \%$. 


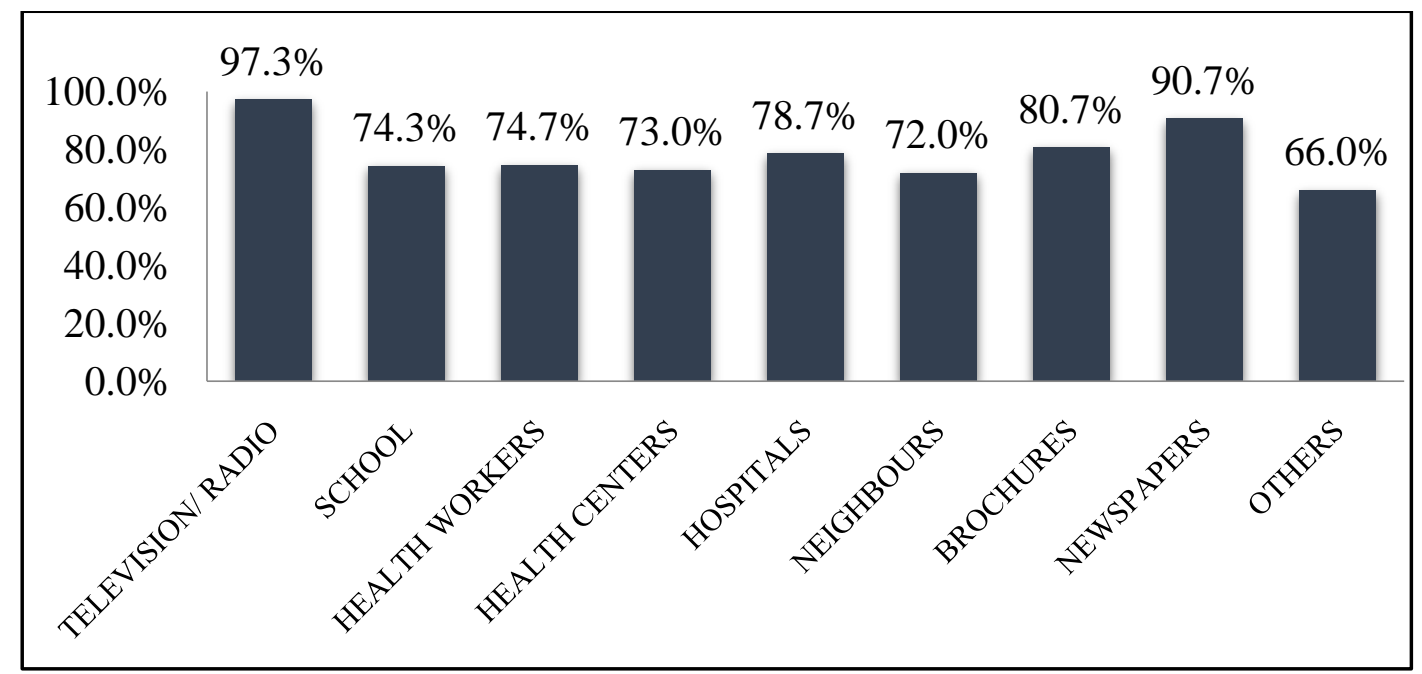

Figure 1: Sources of information regarding dengue fever

Prevalence of knowledge, attitudes, and practices of prevention towards dengue fever The data showed that participants with a good knowledge represent $60.7 \%$ whereas $44.0 \%$ of the participants showed a good attitude and $57.3 \%$ of the participants had a good practice of prevention toward dengue fever. In overall, the participants often had a positive knowledge, a negative attitude and often a good practice of prevention towards dengue fever (Table 2 ).

Table 2: The association between knowledge of dengue fever and socio-demographic variables.

\begin{tabular}{|c|c|c|c|c|c|}
\hline Variable & $\begin{array}{l}\text { Good knowledge } \\
\text { n (\%) }\end{array}$ & $\begin{array}{l}\text { Poor knowledge n } \\
\text { (\%) }\end{array}$ & n OR & $95 \% \mathrm{Cl}$ & P-value \\
\hline \multicolumn{6}{|l|}{ Gender } \\
\hline Male & $61(33.5 \%)$ & 47 (39.8\%) & \multirow{7}{*}{1.3} & \multirow{7}{*}{$0.8-2.1$} & 0266 \\
\hline Female & $121(66.5 \%)$ & $71(60.2 \%)$ & & & \\
\hline \multicolumn{4}{|l|}{ Race } & & \\
\hline Malay & 107 (58.8\%) & 71 (60.2\%) & & & \multirow{4}{*}{0.519} \\
\hline Chinese & $24(13.2 \%)$ & 21 (17.8\%) & & & \\
\hline Indian & $43(23.6 \%)$ & 23 (19.5\%) & & & \\
\hline Others & $8(4.4 \%)$ & $3(2.5 \%)$ & & & \\
\hline \multicolumn{6}{|l|}{ Age group } \\
\hline$<20$ & 17 (9.3\%) & 14 (11.9\%) & & & \multirow{5}{*}{0.612} \\
\hline $20-24$ & 27 (14.8\%) & 17 (14.4\%) & & & \\
\hline $25-29$ & $20(11.0 \%)$ & $17(14.4 \%)$ & & & \\
\hline $30-34$ & 33 (18.1\%) & 25 (21.2\%) & & & \\
\hline$>35$ & $85(46.7 \%)$ & $45(38.1 \%)$ & & & \\
\hline \multicolumn{6}{|l|}{ Marital status } \\
\hline Single & $58(31.9 \%)$ & $41(34.7 \%)$ & & & \multirow{3}{*}{0.778} \\
\hline Married & $122(67.0 \%)$ & 75 (63.6\%) & & & \\
\hline Divorced & $2(1.1 \%)$ & $2(1.7 \%)$ & & & \\
\hline \multicolumn{6}{|c|}{ Family monthly income } \\
\hline$<$ RM 3000 & $142(78.0 \%)$ & $92(78.0 \%)$ & \multirow{2}{*}{1.0} & & \multirow{2}{*}{0.991} \\
\hline > RM 3000 & $40(22.0 \%)$ & $26(22.0 \%)$ & & $0.6-1.7$ & \\
\hline \multicolumn{6}{|l|}{ Living area } \\
\hline Rural & $76(41.8 \%)$ & $52(44.1 \%)$ & \multirow{2}{*}{1.0} & & \multirow{2}{*}{0.991} \\
\hline Urban & 105 (57.7\%) & $66(55.9 \%)$ & & $0.6-1.6$ & \\
\hline \multicolumn{6}{|c|}{ Higher education level } \\
\hline Below SPM & 15 (8.2\%) & 16 (13.6\%) & & & \multirow[t]{5}{*}{0.526} \\
\hline SPM & 96 (52.7\%) & 64 (54.2\%) & & & \\
\hline Diploma & $41(22.5 \%)$ & $24(20.3 \%)$ & & & \\
\hline Degree & $26(14.3 \%)$ & 12 (14.9\%) & & & \\
\hline Master & $4(2.2 \%)$ & $2(2.4 \%)$ & & & \\
\hline
\end{tabular}


The association between knowledge, attitudes, and practices of prevention towards dengue fever with socio-demographic factors

Chi-square test was used to determine the association between knowledge and sociodemographic factors. The association of gender, family monthly income and living area with knowledge status was statistically insignificant with a P-value of 0.266, 0.991 and 0.991 respectively (Table 2 ).

A significant association has been found between attitude score and family monthly income and highest education level as the P-value less than $0.05 ; 0.021$ and 0.013 respectively. However, other socio-demographic factors such as gender, race, age, material status, and living area showed insignificant association with attitude with $\mathrm{P}$-values of $0.764,0.515,0.823,0.922$ and 0.218 respectively (Table 3 ).

There was no significant association between practice and socio-demographic variables towards dengue fever prevention except the race variable with a significant $P$-value of 0.005 (Table 4).

Table 3: The association between attitudes with socio-demographic factors.

\begin{tabular}{|c|c|c|c|c|c|}
\hline Variable & $\begin{array}{l}\text { Positive attitude } \\
\text { n (\%) }\end{array}$ & $\begin{array}{l}\text { Negative attitude } \\
\text { n (\%) }\end{array}$ & OR & $95 \% \mathrm{Cl}$ & P-value \\
\hline \multicolumn{6}{|l|}{ Gender } \\
\hline Male & 73 (35.4\%) & 35 (37.2\%) & \multirow{7}{*}{1.1} & \multirow{7}{*}{$0.7-1.8$} & \multirow{3}{*}{0.764} \\
\hline Female & $133(64.5 \%)$ & $59(62.8 \%)$ & & & \\
\hline \multicolumn{3}{|l|}{ Race } & & & \\
\hline Malay & $125(60.7 \%)$ & $53(56.4 \%)$ & & & \multirow{4}{*}{0.515} \\
\hline Chinese & $28(13.6 \%)$ & $17(18.1 \%)$ & & & \\
\hline Indian & $47(22.8 \%)$ & $19(20.2 \%)$ & & & \\
\hline Others & $6(2.9 \%)$ & $5(5.3 \%)$ & & & \\
\hline \multicolumn{6}{|l|}{ Age group } \\
\hline$<20$ & $21(10.2 \%)$ & $10(10.6 \%)$ & & & \multirow{5}{*}{0.823} \\
\hline $20-24$ & $33(16.0 \%)$ & $11(11.7 \%)$ & & & \\
\hline $25-29$ & $26(12.6 \%)$ & $11(11.7 \%)$ & & & \\
\hline $30-34$ & 37 (18.0\%) & $21(22.3 \%)$ & & & \\
\hline$>35$ & $89(43.2 \%)$ & $41(43.6 \%)$ & & & \\
\hline \multicolumn{6}{|l|}{ Marital status } \\
\hline Single & 69 (33.5\%) & 30 (31.9\%) & & & \multirow{3}{*}{0.922} \\
\hline Married & $134(65.0 \%)$ & $63(67.0 \%)$ & & & \\
\hline Divorced & $3(1.5 \%)$ & $1(1.1 \%)$ & & & \\
\hline \multicolumn{6}{|c|}{ Family monthly income } \\
\hline$<$ RM 3000 & $153(74.3 \%)$ & $81(86.2 \%)$ & \multirow{2}{*}{1.0} & \multirow{2}{*}{$0.6-1.7$} & \multirow{2}{*}{0.021} \\
\hline$>$ RM 3000 & $53(25.7 \%)$ & $13(13.8 \%)$ & & & \\
\hline \multicolumn{6}{|l|}{ Living area } \\
\hline Rural & $83(40.3 \%)$ & $123(59.7 \%)$ & \multirow{2}{*}{1.4} & \multirow{2}{*}{$0.8-2.2$} & \multirow{2}{*}{0.218} \\
\hline Urban & $45(47.9 \%)$ & $49(52.1 \%)$ & & & \\
\hline \multicolumn{6}{|c|}{ Higher education level } \\
\hline Below SPM & 17 (8.3\%) & $14(14.9 \%)$ & & & \multirow{5}{*}{0.013} \\
\hline SPM & $102(49.5 \%)$ & $58(61.7 \%)$ & & & \\
\hline Diploma & $53(25.7 \%)$ & $12(12.8 \%)$ & & & \\
\hline Degree & $28(13.6 \%)$ & 10 (10.6\%) & & & \\
\hline Master & $6(2.9 \%)$ & $0(0.0 \%)$ & & & \\
\hline
\end{tabular}

The association of knowledge with both attitudes and practices

There was no significant association between knowledge and attitude since the $P$-value is 0.208 (Table 5). However, there was a significant association between knowledge and practice towards dengue prevention (Table 6). Those respondents who have good knowledge have better practice towards dengue prevention. 
Table 4: The association between practices with socio-demographic factors.

\begin{tabular}{|c|c|c|c|c|c|}
\hline Variable & $\begin{array}{l}\text { Good practice } \\
\text { n (\%) }\end{array}$ & $\begin{array}{l}\text { Bad practice } \\
\text { n (\%) }\end{array}$ & OR & $95 \% \mathrm{Cl}$ & P-value \\
\hline \multicolumn{6}{|l|}{ Gender } \\
\hline Male & 67 (39.0\%) & 41 (32.0\%) & \multirow{7}{*}{0.7} & \multirow{7}{*}{$0.5-1.2$} & \multirow{3}{*}{0.217} \\
\hline Female & $105(61.0 \%)$ & 87 (68.0\%) & & & \\
\hline \multicolumn{3}{|l|}{ Race } & & & \\
\hline Malay & $110(64.0 \%)$ & 68 (53.1\%) & & & \multirow{4}{*}{0.005} \\
\hline Chinese & 15 (8.7\%) & 30 (23.4\%) & & & \\
\hline Indian & $41(23.8 \%)$ & 25 (19.5\%) & & & \\
\hline Others & $6(3.5 \%)$ & $5(3.9 \%)$ & & & \\
\hline \multicolumn{6}{|l|}{ Age group } \\
\hline$<20$ & 18 (10.5\%) & 13 (10.2\%) & & & \multirow{5}{*}{0.963} \\
\hline $20-24$ & $26(15.1 \%)$ & 18 (14.1\%) & & & \\
\hline $25-29$ & $23(13.4 \%)$ & $14(10.9 \%)$ & & & \\
\hline $30-34$ & 32 (18.6\%) & $26(20.3 \%)$ & & & \\
\hline$>35$ & $73(42.4 \%)$ & $57(44.5 \%)$ & & & \\
\hline \multicolumn{6}{|c|}{ Marital status } \\
\hline Single & $52(30.2 \%)$ & $47(36.7 \%)$ & & & \multirow{3}{*}{0.182} \\
\hline Married & $119(69.2 \%)$ & 78 (60.9\%) & & & \\
\hline Divorced & $1(0.6 \%)$ & $3(2.3 \%)$ & & & \\
\hline \multicolumn{6}{|c|}{ Family monthly income } \\
\hline$<$ RM 3000 & $136(79.1 \%)$ & $98(76.6 \%)$ & \multirow{3}{*}{0.9} & \multirow{3}{*}{$0.5-1.5$} & \multirow{2}{*}{0.604} \\
\hline >RM 3000 & $36(20.9 \%)$ & 30 (23.4\%) & & & \\
\hline \multicolumn{4}{|c|}{ Living area } & & \\
\hline Rural & 77 (44.8\%) & 51 (39.8\%) & \multirow{2}{*}{0.8} & \multirow{2}{*}{$0.5-1.3$} & \multirow{2}{*}{0.411} \\
\hline Urban & $95(55.2 \%)$ & $77(60.2 \%)$ & & & \\
\hline \multicolumn{6}{|c|}{ Higher education level } \\
\hline Below SPM & $14(8.1 \%)$ & $17(13.3 \%)$ & & & \multirow{5}{*}{0.053} \\
\hline SPM & 98 (57.0\%) & 62 (48.4\%) & & & \\
\hline Diploma & $41(23.8 \%)$ & $24(18.8 \%)$ & & & \\
\hline Degree & $18(10.5 \%)$ & 20 (15.6\%) & & & \\
\hline Master & $1(0.6 \%)$ & $5(3.9 \%)$ & & & \\
\hline
\end{tabular}

\section{DISCUSSION}

In this study, it has been found that the knowledge towards dengue fever was fair (60.9\%). Mostly, similar findingshave been reported in previous studies done in Kuala Lumpur ${ }^{(26)}$, Negeri Sembilan ${ }^{(27)}$, Terengganu ${ }^{(28)}$, Sri Lanka ${ }^{(29)}$, and India ${ }^{(30)}$. In contrast, a recent study, which has been done in urban, semi-urban and rural communities in Malaysia, demonstrated a higher rate of knowledge $(89.7 \%)$ towards dengue fever ${ }^{(25)}$. This could be attributed to that different region could have different knowledge. Interestingly, another study showed the highest rate $(96.8 \%)$ of the public have knowledge towards dengue fever was done in Perak state in Malaysia ${ }^{(31)}$.

Our result also showed that the most common source of information is from television and radio $97.3 \%$ followed by newspaper $90.7 \%$. Several studies have been reported similar result on the source of information that ranged from $85.0 \%$ to $97.0 \%{ }^{(25-27)}$. However, Abdullah et al., demonstrate that newspaper was the common source of information regarding dengue fever $91.4 \%{ }^{(31)}$. Moreover, a study that has been done in Lao PDR revealed that friend and relatives are the most common source of information $43.9 \%$ (32). This could be attributed to that different region such as urban, semi-urban and rural communities could have the different source of information.

On the other hand, our data showed that most respondents have a good knowledge and ability to identify of the dengue fever symptoms, especially rash $(91.0 \%)$ followed by joint pain $(83.7 \%)$ and fever $(83.3 \%)$. This is similar to the previous study have been done in Malaysia where chills and high fever, intense headache, muscle and joint pains are the most common presentation of dengue fever $95 \%{ }^{(25)}$. Moreover, another study also revealed that $78.2 \%$ of respondents able to identify one clinical sign and symptom of dengue fever and most clinical presentations are sudden onset of fever ${ }^{(26)}$. 
Table 5: The association between knowledge and attitude.

\begin{tabular}{lllll}
\hline \multicolumn{1}{c}{ Variables } & \multicolumn{1}{c}{$\begin{array}{c}\text { Positive attitude } \\
\mathrm{n}(\%)\end{array}$} & $\begin{array}{c}\text { Negative attitude } \\
\mathrm{n}(\%)\end{array}$ & X2 (df) & P-value \\
\hline Good knowledge & $84(46.2 \%)$ & $98(53.8 \%)$ & & \\
Poor knowledge & $48(40.7 \%)$ & $70(59.3 \%)$ & 1 & 0.208 \\
Total & 132 & 168 & & \\
\hline
\end{tabular}

Table 6: The associations between knowledge and practice.

\begin{tabular}{llllc}
\hline Variables & $\begin{array}{l}\text { Good practice } \\
\mathrm{n}(\%)\end{array}$ & $\begin{array}{l}\text { Bad practice } \\
\mathrm{n}(\%)\end{array}$ & $\mathrm{X}$ (df) & P-value \\
\hline Good knowledge & $119(65.4 \%)$ & $63(34.6 \%)$ & & \\
Poor knowledge & $53(44.9 \%)$ & $65(55.1 \%)$ & 1 & 0.00 \\
Total & 172 & 128 & & \\
\hline
\end{tabular}

The current study shows a good knowledge on transmission of dengue fever where $91 \%$ of respondents able to identify Aedes mosquito as a vector of dengue virus. This finding is consistent with previous studies that showed $97.7 \%$ (25) $73.0 \%{ }^{(26)}$ of the respondents were aware of the dengue viruses vectors. Similarly, Knowledge on dengue prevention was excellent in the present study as more than $95 \%$ have the information regarding the prevention of mosquitoes breeding by removal of standing water, reduces the mosquitoes by cutting down bushes and kill mosquito larvae by pouring chemicals in standing water. This result constant with previous studies that showed clogged drains a possible place for the mosquito to breed ${ }^{(26)}$ and stagnant water is the main source of mosquito breeding ${ }^{(25,27)}$.

This study found that positive attitude towards dengue fever is only $44 \%$ despite having good knowledge towards dengue fever. Similarly, it has been previously reported that it is not necessary that knowledge about dengue fever could be translated to positive attitudes (3, ${ }^{33)}$. Previous studies show positive attitudes towards dengue fever where starts from $83.3 \%$, $80.0 \%, 75.2 \%$ to $63.8 \%(26,27,30,31)$. More than half of respondents $(59.7 \%)$ believe that fogging is not essential for prevention of dengue. This is similar to the previous study conducted in Malaysia where $67.3 \%$ respondents disagree fogging by the municipal council is essential enough for prevention of dengue ${ }^{(25)}$. This shows that respondents are unaware of the importance and how effective fogging is to reduce mosquito and dengue.

The practice to prevent dengue fever is fair (57.3\%) which is similar to the previous study that showed $49.6 \%{ }^{(26)}$. Other studies show a higher level of preventive measure practices towards dengue fever; $76 \%$ and $79.7 \%(27,31)$. The most common practices used by respondents to prevent the dengue were the frequently cleaning the water-filled containers and ditches around their house $(93.3 \%)$, followed by the covering of water containers at home $(90.3 \%)$ and covering the water tanks at home (89.3\%). These findings were consistent with those reported by previous studies $(25,27,31)$. However, this study shows that only $37.3 \%$ of respondents' use professional pest control abate (Temephos) to reduce mosquitoes which are higher to $18 \%$ as reported by a previous study ${ }^{(25)}$.

There was no any association between the knowledge and the socio-demographic factors. This is similar to the previous study conducted in Jamaica ${ }^{(30)}$. In contrast to our finding, Rozita et al., (2006), reported a significant link between education level and knowledge where the secondary to tertiary-educated respondents have more knowledge compared to respondents that have no formal to primary education. Likewise, a study conducted in Negeri Sembilan showed that age group, ethnicity, and education level have a significant association with knowledge ${ }^{(27)}$. Our data also revealed that Chinese have higher knowledge followed by Malays, Indians, and others.

Al-Dubai etal., (2013) found a significant association between attitudes and both levels of education and employment status. This was similar to another study that done previously by Leong etal., (2014) where education level and ethnicity have a significant association towards attitudes of respondents. This is similar to the findings of Rozita et al., (2006) where higher education level has positive attitudes towards dengue fever. Our data also reported that there is a significant association between attitude and gender, where the female tends to have a more positive attitude towards dengue fever. Nevertheless, the current study found that there is an association between attitudes and education level and family income only.

The association between the practice and respondent race was significant. This finding was 
consistent with an earlier study done by Rozita et al., (2006). In Malaysia, it has been described that among selected urban, semi-urban and rural communities there is a significant association between practice level and both age group and geographical area. It is reported that rural area has higher levels of practice towards dengue fever due to the presence of stronger sociocultural bonds among rural communities in Malaysia. A study conducted by Leong etal., (2014) shows a significant association between practice level and both ethnicity and marital status.

There is no significant association between knowledge and attitude. Among 182 respondents with good knowledge, only $46.2 \%$ have positive attitudes towards dengue. This shows that despite having good knowledge towards dengue but still public have a negative attitude in the role of preventing dengue. These findings are similar to earlier studies ${ }^{(25,27)}$. However, there is another study reported that there is a significant association between knowledge and attitude ${ }^{(34)}$.

Finally, the study showed a significant association between knowledge and practice. Among 182 respondents who have a good knowledge, $65.4 \%$ have a good practice. Among 118 respondents with poor knowledge, only 44.9\% have the good practice which means that public with good knowledge will have better practices. It also showed that people with good knowledge tend to act and involve in practice to prevent their surroundings from the breeding of mosquitoes and dengue fever. These findings are similar to the previous study done in Malaysia ${ }^{(25)}$. In contrast, previous authors have reported an insignificant association between knowledge and practice $^{(27)}$.

\section{CONCLUSIONS}

In a nutshell, the results of this study showed that the respondents have moderateknowledge towards dengue fever, but the attitude towards dengue fever still poor because the respondents have a lack of insight and are not worried about the effects of dengue outbreak. However, in this study, it has been reported that respondents with good knowledge have better practices compared to respondents with poor knowledge. Therefore, the finding of this study has alerted us that, more activities toward dengue based programs such as dengue campaigns, talks, school health program, community collaboration activities should be done not only to expose them with knowledge but also to fertilize the seed of good attitude and standpoint regarding dengue and its impact to the public. This program should be started first from school levels so that, it can educate children at an early age. Even though these activities have been established for some time, comprehensive results could be established and achieved by the cooperation of individual, community, government and mass media. Finally, everyone should play a role in eradicating dengue outbreak not only in Malaysia but worldwide.

\section{ACKNOWLEDGEMENTS}

Thanks are addressed to the Director of Hospital Taiping, Clinical Research Centre of Hospital Taiping and Head of Department of Medicine Dr. Umathevi and Head of Department of Paediatrics Dr. Saiful Rijal.

\section{CONFLICT OF INTERESTS}

The authors have declared that no conflict of interest exists.

\section{FUNDING}

This study was supported by Management and Science University (MSU) Seed Grant Number: SG 379-0216-IMS. The funders had no role in study design, data collection, and analysis, decision to publish, or preparation of the manuscript.

\section{REFERENCES}

1. Alhoot MA, Rathinam AK, Wang SM, et al. Inhibition of dengue virus entry into target cells using synthetic antiviral peptides. Int. J. Med. Sci. 2013;10(6):719-29.

2. Alhoot MA, Wang SM, Sekaran SD. Inhibition of dengue virus entry and multiplication into monocytes using RNA interference. PLOS Negl. Trop. Dis. 2011;5(11):e1410.

3. Talarico L, Pujol C, Zibetti R, et al. The antiviral activity of sulfated polysaccharides against dengue virus is dependent on virus serotype and host cell. Antiviral Res. 2005;66(2):103-10.

4. Alhoot MA, Wang SM, Sekaran SD. RNA interference mediated inhibition of dengue virus multiplication and entry in HepG2 cells. Plos one. 2012;7(3):e34060.

5. Padmanabhan $\mathrm{P}$, Khaleefathullah $\mathrm{S}$, Kaveri K, et al. Antiviral activity of Thiosemicarbazones derived from alpha-amino acids against Dengue virus. J Med Virol. 2017;89(3):546-52.

6. $\mathrm{Pu} \mathrm{J}, \mathrm{He} \mathrm{L}$, Xie $\mathrm{H}$, et al. Antiviral activity of Carbenoxolone disodium against dengue virus infection. $J$ Med Virol. 2017;89(4):571-81. 
7. Natarajan S. NS3 protease from flavivirus as a target for designing antiviral inhibitors against dengue virus. Genet. Mol. Biol. 2010;33(2):2149. PubMed PMID: 21637471.

8. Zhang XG, Mason PW, Dubovi EJ, et al. Antiviral activity of geneticin against dengue virus. Antiviral Res. 2009;83(1):21-7.

9. World Health Organization. Fact sheet: Dengue and severe dengue. 2016 fs117.

10. Bellini R, Zeller H, Van Bortel W. A review of the vector management methods to prevent and control outbreaks of West Nile virus infection and the challenge for Europe. Parasit Vectors. 2014 07/11

11. López-Gatell H, Alpuche-Aranda CM, Santos-Preciado JI, et al. Dengue vaccine: local decisions, global consequences. Bull. World Health Organ. 2016;94(11):850-5.

12. Griffitts $T$, Hanson $H$. Significance of an epidemic of dengue. J. Am. Med. Assoc. 1936;107(14):1107-10.

13. Murray NEA, Quam MB, Wilder-Smith A. Epidemiology of dengue: past, present and future prospects. Clin. Epidemiol. 2013;20(5)299-309.

14. Brady OJ, Gething PW, Bhatt S, et al. Refining the global spatial limits of dengue virus transmission by evidencebased consensus. PLOS Negl. Trop. Dis. 2012;6(8):e1760.

15. Bhatt S, Gething PW, Brady OJ, et al. The global distribution and burden of dengue.Nature. 2013;496(7446):504-7.

16. World Health Organization. Technical Paper "Dengue: Call for urgent interventions for a rapidly expanding emerging disease". Regional Committee for the Eastern Mediterranean 2011 $\mathrm{EM} / \mathrm{RC} 58 / 3$.

17. World Health Organization SEARO. Comprehensive Guidelines for Prevention and Control of Dengue and Dengue Haemorrhagic Fever (Revised and expanded edition). India: World Health Organization Regional Office for South East Asia: 2011.

18. Skae FM. Dengue Fever in Penang. BMJ. 1902;2(2185):1581-2.
19. Smith CE. The history of dengue in tropical Asia and its probable relationship to the mosquito Aedes aegypti. Am J Trop Med Hyg. 1956;59(10):243-51.

20. Rudnick A, Tan EE, Lucas JK, et al. Mosquito-Borne Haemorrhagic Fever in Malaya. BMJ. 1965;1(5445):1269-72.

21. Wallace HG, Lim TW, Rudnick A, et al. Dengue hemorrhagic fever in Malaysia: the 1973 epidemic. Southeast Asian J Trop Med Public Health. 1980;11(1):113.

22. Poovaneswari S. Dengue situation in Malaysia. Malays J Pathol.1993;15(1):37.

23. Herriman R. Malaysia dengue fever cases top 120,000 for 2015; Selangor state reports more than half. Outbreak News Today 2016.

24. MOH. Kenyataan Akhbar Ketua Pengarah Kesihatan Malaysia Situasi Semasa Demam Denggi Di Malaysia Bagi Minggu 52/2011 (25 Hingga 31 Disember 2011). In: Malaysia KK, editor. Putrajaya Kementerian Kesihatan Malaysia; 2012.

25. Al-Dubai S, Ganasegeran K, Mohanad Rahman A, et al. Factors affecting dengue fever knowledge, attitudes and practices among selected urban, semiurban and rural communities in Malaysia. Southeast Asian J Trop Med Public Health. 2013;44(1):37-49.

26. Wan Rozita W, Yap B, Veronica S, Mohammad A, et al. Knowledge, attitude and practice (KAP) survey on dengue fever in an urban Malay residential area in Kuala Lumpur. Malays $J$ Public Health Med. 2006;6(2):62-7.

27. Leong TK. Knowledge, Attitude and Practice on Dengue among Rural Communities in Rembau and Bukit Pelanduk, Negeri Sembilan, Malaysia.Int J Trop Dis Health.2014;4(7): 841-848.

28. Aung MT, Hassan AB, Kadarman NB, et al. Knowledge, Attitude, Practices Related To Dengue Fever Among Rural Population In Terengganu, Malaysia.MJPHM.2016, 16(3):15-23.

29. Gunasekara T, Velathanthiri V, Weerasekara $M$, et al. Knowledge, 
attitudes and practices regarding dengue fever in a suburban community in Sri Lanka. Galle Medical Journal. 2012;17(1):10-17.

30. Shuaib F, Todd D, Campbell-Stennett D, et al. Knowledge, attitudes and practices regarding dengue infection in Westmoreland, Jamaica. West Indian Med J. 2010;59(2):139-46.

31. Abdullah MN, Azib W, Harun MFM, et al. Reliability and Construct Validity of Knowledge, Attitude and Practice on Dengue Fever Prevention Questionnaire. 2013 IEEE Symposium on Humanities, Sciences andEngineering Research (SHUSHER); 2013.

32. Nalongsack S, Yoshida $Y$, Morita $S$, et al. Knowledge, attitude and practice regarding dengue among people in Pakse, Laos. Nagoya J Med Sci. 2009;71(1-2):29-37.

33. Wilder-Smith A, Ooi E-E, Vasudevan SG, et al. Update on dengue: epidemiology, virus evolution, antiviral drugs, and vaccine development. Curr Infect Dis Rep. 2010;12(3):157-64.

34. Hairi $\mathrm{F}$, Ong $\mathrm{C}-\mathrm{H}$, Suhaimi $\mathrm{A}$, et al. A knowledge, attitude and practices (KAP) study on dengue among selected rural communities in the Kuala Kangsar district. Asia Pac J Public Health. 2003;15(1):37-43. 